\title{
AC Kids: Art of Cooking for Kids
}

\author{
Siti Rodliyah Ummus Sholihah \\ Faculty of Education \\ Universitas Negeri Malang \\ Malang, Indonesia \\ siti.rodliyah23@gmail.com
}

\author{
Nurima Trissia \\ Faculty of Education \\ Universitas Negeri Malang \\ Malang, Indonesia \\ nurimatrissia58@gmail.com
}

\author{
Andini Mukharoma Meidina \\ Faculty of Education \\ Universitas Negeri Malang \\ Malang, Indonesia \\ andinimukharoma@gmail.com
}

\begin{abstract}
The growth of children aged 4-8 years is influenced by the provision of nutrients with the right quality and quantity. Nutrition fulfillment of meals is one effort in fulfilling the requirement of vitamin and mineral of child. Therefore, in order to optimize the quality and quantity of children's nutritional meals can be done by providing a healthy food provision. Provision of healthy food supplies for children can be done by providing nutrition consultation facilities both offline and online. In addition to paying attention to the nutritional needs of each child, this business also provides children's creative development services through cooking classes. The price offered is affordable for all levels of society considering the purpose of this business is the fulfillment of child nutrition.
\end{abstract}

Keywords - healthy food, cooking class, creativity, early childhood.

\section{INTRODUCTION}

Children are an investment nation because they are the next generation of the nation. The quality of the nation in the future is determined the quality of children today. Efforts to improve the quality of human resources must be done early, systematic and sustainable. Growing development of schoolage children is optimal depending on the provision of nutrients with good quality and quantity as well as true. In this period of growth, the provision of nutrition or food intake in children is not always perfect. Nutrition affects bone growth, body shape and their susceptibility to viruses and diseases [1]. In connection with this, Slentz concluded that the early learning and development benchmarks provide a set of general developmental expectations for what youngsters should know and be able to do at 18 months, 36 months, 60 months, and kindergarten entry [2]. It is differentiated in five interrelated areas of development: (1) physical/health/motor; (2) social and emotional; (3) approaches toward learning; (4) cognition and general knowledge; and (5) language, literacy, and communication. In Slentz's opinion, aspects of development that need to be considered are physical health and motor skills, where nutritional intake has great control in achievement. Given all aspects of mutual sustainability, then to achieve the five aspects of child development requires special attention and handling.

Harinda dan Setiawati explained that at the age of preschool, children experience psychic development become toddler which more independent, can interact with its environment, and can express emotion [3]. Children are also often fussy at meals if this situation is not addressed can develop into problems associated with appetite. Complaints about the child's appetite become a problem that is often expressed by parents. This complaint is almost evenly regardless of gender, ethnicity and socioeconomic status. Some eating problems that often arise include fussy, vomiting, too picky, eating phobia, slow eating, and rejection of eating. There are many factors that affect the appetite for children, one of the triggers is the habit of carrying pocket money and snacks are very popular among school children in Indonesia. Kids' favorite snacks are usually packaged foods that have attractive packaging, attractive colors and a strong enough taste. The snacks accounted for $36 \%$ of the school's energy intake, $29 \%$ protein and $52 \%$ iron. Therefore, it can be understood the important role of food snacks on growth and learning achievement of school children. However, the security of snacks both in terms of microbiological and chemicals need to be questioned.

Based on this, AC Kids emerged as a provider of the provision of healthy food for children aged 4-8 years. This food supply can be ordered according to taste with an affordable price, delicious taste, and fast response in delivering meals. In addition, the food will be packaged in an interesting and unique way. This is because the design of the shape, color, and taste of these food supplies can attract the attention of children and increase the appetite of children. Other programs offered include cooking classes and nutrition consultations online and offline.

The purpose of this activity can be formulated as follows; (a) describes the role of this caterer in improving healthy nutrition for children, (b) knowing the production flow and catering services of children and their marketing, (c) opening new business opportunities by marketing products directly and through online. The benefits are as follows; (a) provide services for children to obtain healthy food and meet balanced nutrition guidelines through catering lunch supplies; (b) familiarize children for lunch with unique dishes and attractive packaging through cooking class activities; (c) opening new jobs so that they can absorb the workforce to work as cooks, nutritionists, and other healthy food entrepreneurs; (d) be a means of implementing skills, skills, responsibilities, and (e) building student co-operation to prepare themselves creative and independent entrepreneurs components, incorporating the applicable criteria that follow.

\section{METHOD}

Pricing strategy is based on producer price. The price set is the price directly from the initial producers (farmers, fishermen, ranchers), so the price is lower than the market price. In addition, any food can be guaranteed quality because it can choose directly. Meanwhile, for partners who cooperate, the price is determined according to an agreed agreement. Marketing strategy is to analyze market 
opportunities and choose market segmentation appropriately [4]. Then determine the promotion strategy and product pricing according to market segmentation. Promotion is done both online and off-line. On-line is through social media to accommodate consumer orders [5]. Promotion through offline is done by an open house in schools and giving brochures and giving samples. Supervision, evaluation, and improvement are always done to create new innovations in order to maintain the satisfaction of children aged 4-8 years (as a consumers). Targeted targets for entrepreneurs are teachers and parents or parents of children of PAUD (Kindergarten/ Daycare) and SD/MI (elementary school) so that these products can be directly delivered to children. But children can also order themselves.

Another effort that is done by doing socialization and demonstration to the community. The activities are presented with interesting concepts such as educative games, the introduction of food and its benefits, storytelling and so forth. With this activity, children are expected to be interested to eat according to nutritional needs through a series of fun activities.

\section{RESULT AND DISCUSSION}

\section{A. Creativity in The Culinary Business}

business, creativity is an absolute thing to have. In starting a culinary business, this can be done by mixing present-day tastes with pre-existing recipes [6]. Success in the culinary field requires the emergence of new ideas. The resulting idea must be truly unique and different. By carrying out business ideas that are not the same as others, the products produced will be more acceptable and less competitive [4]. The culinary business that is currently on the rise, for example, martabak and kue cubit with various flavors, seems simple and ordinary. But the success of this business is the result of endless creativity. Creations in the culinary business can also be done with other recipes. This can be tried by carrying food or drinks that are already popular in the community then developing it with a variety of flavors.

Culinary business is now one of the most promising business to run. This business prospect will continue to be brilliant considering the culinary or the food is a staple for all human beings. One of the culinary business that can be run is a food catering business. Catering food is a business that belongs to home-based small business and very much in demand. In addition, this food catering can provide a relatively large income potential, with profits can reach $50 \%$ of fund. Especially, there is still very rare for special catering for children. The choice of food menu can also be adjusted orders while still taking into account the balanced nutrition for children.

To cultivate the culinary business, besides creativity related to products, creativity is also needed to develop the appearance of the product [7]. In terms of location sometimes in starting this business, there is no need to rent a kiosk at a high price. There are several locations that can be used, such as a house terrace. In addition to selling on the porch, sales can also be done by entrusting merchandise to food stalls to cake shops. If you have trouble finding a shop that is willing to be entrusted with merchandise, sales can also be done with cars that are deliberately parked in spots that are indeed crowded with buyers.

\section{B. Promotion in The Culinary Business}

After maturing determine the type of snack and start production, the promotion can begin to spread it to the closest person. From family, friends, to acquaintances. If needed, the product can be brought while gathering with colleagues. Also give a tester for free so it can try and attract buyers. Who knows the closest colleague will be the main customer. Social media can indeed be used as a powerful vehicle to bring business to success [5]. Take advantage of free applications like Facebook, Twitter, and Instagram to grow your business. Even in today's digital era, special websites can be created so that the products marketed look more reliable.

Currently, communication technology is growing very rapidly in Indonesia. Ease of internet network access is also one of the supporting factors for the development of this communication technology. Through the utilization of this communication technology development, the authors intend to develop catering service innovation through online so that people can access easily and very affordable price. The huge market potential and technological advances make the service providers healthy food providers have a very promising prospect [7]. In addition, the advantages of this service are the availability of consultations on improving nutrition. Parents, teachers, and the community can do nutrition consultation directly or online. As long as there is no catering that provides consultation, so this business opportunity is very potent.

To increase sales, marketing strategies can also be done by defending famous artists. In addition, in product marketing through social media can also pay attention to the shooting technique so that the product looks more tempting. The saying "Don't judge by its cover" does not apply when developing a business in the food sector. In order to increase your product sales sharply, product packaging needs to be considered carefully. Product design is made as unique as possible so that prospective customers want to try because they have fallen in love with the package [8].

At the beginning of this business, there was no need to install expensive prices to get high profits. Even though the profit per product is only a little, but if the demand is high, the entrepreneur can pocket a lot of profits. Keep the taste and quality of the product and just agitate to advertise to attract customers, this way the demand for products will also increase [8].

Indeed, at the beginning of pioneering the food business, the product will not sell well. Everything needs a struggle in order to ensnare many customers [7]. The most important thing is to remain consistent to produce so that the culinary business that is developed can still walk forward. Consistent in production is done so that when there are requests that can still be fulfilled, this will also prevent customers from losing.

To work in the culinary business, must be diligent to develop products sold. This is so that the business does not just run in place. Always innovating will make buyers always interested in trying and will make the business more successful in the future.

\section{Catering Business for Children}

This catering business has a target in early childhood and elementary school age children. Excellent program that is cooking class. Children are freed to form their own food they 
want to decorate. Creativity and imagination of children can be poured in the form of food. A wide selection of healthy and tasty food is ready in ornamental and consumed by children. Food served is packaged in such a way as to appeal to children. This child's interest will help improve their appetite. The nutritional value of the diet has also been calculated according to the age of the child [9]. The calculation of the number of the child's nutritional adequacy will help ensure the child has the nutrition it need.

A child catering business can be developed for several reasons. This can be due to complaints from parents because children turn into picky eater. Sometimes children want food given at home, but more often do not eat three times a day like adults. This also encourages parents to look for alternatives to regulate a child's diet that is unique to him. In this way, the child's nutritional needs remain fulfilled even though he does not eat three times a day. Catering can be developed by providing a main food menu and snacks. This method can also help parents analyze the type of food the child likes and how much the child needs [9].

The limitation of parents in preparing menus that children like is also an opportunity in this catering business. Although there is no need to be reminded again, that the best food for children who are growing up is food made at home. However, instead of introducing children to fast food, it is better to use catering services that also consider the nutritional needs of children. The menu that needs to be restricted to children is the dessert which includes sugarbased foods or drinks. Foods that contain high sugar are usually low in nutrients and minerals. Instead, it can be used as a fruit menu that is modified in such a way as to attract children's attention [10].

In addition, the menu comes from full fat milk to ensure the child gets the right nutrition. The key to parents' mistakes in fulfilling these nutrients is usually due to forcing children to eat. It's natural for children to measure how much they want to eat and when they will eat [10]. Sometimes they refuse new food or change their minds before biting the food given. Or at different times, children actually want the same food for several days in a row. So, the best way is to test what children like and what they don't like.

By paying attention to the child's diet, the child will have a good eating plan and he will have healthy eating habits. In addition, the child's diet becomes regular so parents don't have to worry anymore about whether their nutritional needs are met. The main focus on children diet is their health. Many health problems that arise at the age of the child are overweight. However, if this weight gain occurs during puberty, this should not be a concern because this is a normal thing. Because the changes in the child's body (coupled with exercise) will help reduce the child's weight to get the ideal body shape. Increased weight gain in children is caused by the child's body has a higher hunger sensitivity compared to adult age. The more children are left hungry with high levels of hunger sensitivity, the slower the metabolic process in their bodies. Actually, children do not need to go on a diet that limits calories or certain types of food. Especially if children have body weight in the normal category. The reason is, children are still in the phase of growth and development so that children need healthy food to keep their body growing well.
Diet efforts that are carried out too early risk the child's growth to become stagnant. A study shows that diet children can experience physical and emotional problems that last into adulthood [9]. In fact, if left unchecked, children can be at high risk of having eating disorders that can be carried away to adults, such as anorexia nervosa or become picky eater (picky food). For cases of overweight in children, if not treated immediately can cause health problems. However, if forced to do a diet can actually cause new health problems. Children will experience a higher spike in appetite so they cannot control it. As a result, the risk of obesity is even greater. The most effective way for children is to change the eating and thinking of the whole family member. Parents must be able to provide examples of the application of a healthy lifestyle for children. Not only focused on the child's weight loss, but also to maintain the quality of his health in the future.

Promotion efforts that have been done into this program both online and offline. Online is through a variety of social media, as well as content and attractive appearance. Offline by distributing flyers to schools and participating in creative product events and collaborating on community activities. One of the results that have been achieved is by holding cooperation with students who do the program Community Service Program (KKN). turnover is gained that is big enough profit. Products are increasingly recognized by the masses, especially with cooking programs. From KKN activities can also be observed a change in attitude in children who initially difficult when invited to eat now they are willing to wait for the meal.

According to some children, their appetite is growing when the food menu is varied and there is a cooking class [10]. In addition to developing the culinary business for children in the form of child catering, this program also uses cooking class strategies for children. This activity is carried out so that when parents are deserted, parents can invite children to practice what he learned in cooking classes together at home.

Cooking class also has several benefits for children [11]. This activity can improve children's numeracy skills. Cooking is the most powerful way to learn mathematics. When cooking without feeling the child learns how to measure the amount of food from an existing recipe, for example two eggs, half a tablespoon of flour, and so on. This activity can also build children's understanding. Even though children cannot read yet, by cooking children can learn to build understanding of the concept step by step. Starting from the first step, for example peeling food ingredients, then cutting, giving spices until cooked until cooked. Cooking is also part of a science experiment. Too much salt or sugar and too little eggs can cause the dough to fail. This is tantamount to learning science. This activity can produce a work including cooking, which can increase the child's confidence. To be maximal, label the results of the cooking using the child's name, for example Kyle's noodle or Arthur's cookie.

The atmosphere that is formed in the kitchen or cooking class can make children more relaxed to talk about anything. This moment you can use to communicate freely with children, besides in cooking classes, children can socialize with peers. Cooking also trains children's motor skills, just like learning to drive or learning to read. This will train the child's life skills so that the child can be responsible for doing these things [11]. Learning to cook is a fun and super 
fun activity. Learning to cook can be an unforgettable moment for children. Especially if they cooks with the parents, they will bring beautiful memories to adulthood.

\section{CONCLUSION}

In an effort to fulfill the nutrition of children from an early age, it is a necessary effort to increase the child's food intake. Most children have a low appetite due to the food menu is not varied so boring. Therefore, it takes a catering business that offers several kinds of menus with an interesting visual form. This catering business provides cooking classes that can be used as a medium for the development of children's creativity as well as attract children to eat. So with the existence of this catering business, in addition to the fulfillment of nutritional intake, children can improve creativity from an early age.

\section{REFERENCES}

[1] J. W. Santrock, "Masa perkembangan anak," Jkt. Salemba Humanika, 2011

[2] K. L. Slentz, "A guide to assessment in early childhood: Infancy to age eight," Wash. State Off. Supt. Public Instr., 2008.

[3] L. Harinda and E. M. Setiawati, "proporsi dan status gizi pada anak prasekolah dengan kesulitan makan di semarang:(Studi Kasus di Kelurahan Tandang dan Sendangguwo)," PhD Thesis, Fakultas Kedokteran, 2012
[4] M. J. Baker, Marketing strategy and management. Macmillan International Higher Education, 2014.

[5] J. Strauss and R. D. Frost, E-marketing: Instructor's Review Copy. Routledge, 2016.

[6] S. M. G. Tambunan and M. R. Widhiasti, "'You are what you eat... and post': An analysis of culinary innovation and cultural branding in Panggang Ucok's Instagram account,” Cult. Dyn. Glob. World, 2018.

[7] J. C. Cross, T. J. Belich, and W. Rudelius, "How marketing managers use market segmentation: An exploratory study," in Proceedings of the 1990 Academy of Marketing Science (AMS) Annual Conference, 2015, pp. 531-536.

[8] A. M. Muhar and A. Junita, "The Product Mapping and the Market Segmentation to Determine the Strategy to Enhance the Business Competition of the Medan Students," in Prosiding International conference on Information Technology and Business (ICITB), 2016, pp. $41-48$.

[9] S. A. Bowman, S. L. Gortmaker, C. B. Ebbeling, M. A. Pereira, and D. S. Ludwig, "Effects of fast-food consumption on energy intake and diet quality among children in a national household survey," Pediatrics, vol. 113, no. 1, pp. 112-118, 2004.

[10] N. K. Edens, S. Sharma, S. Folkens, A. Wojtowicz, N. Ranjit, and A. Evans, "Experiential cooking and nutrition education program improves fruit and vegetable liking, vegetable consumption, and cooking at home in elementary and middle school children," FASEB J., vol. 30, no. 1_supplement, pp. 676-13, 2016.

[11] D. Hersch, L. Perdue, T. Ambroz, and J. L. Boucher, "Peer reviewed: the impact of cooking classes on food-related preferences, attitudes, and behaviors of school-aged children: a systematic review of the evidence, 2003-2014,” Prev. Chronic. Dis., vol. 11, 2014 